\title{
44. PETROLOGY OF BASALTS, LEG 41
}

\author{
V.V. Eremeev, Geological Institute of the USSR Academy of Sciences, Moscow
}

In the course of Leg 41 the basalts were penetrated by two holes-367 and 368. We have studied 14 samples of rocks in thin sections. A complete silicate analysis was performed on 12 samples. The results are summarized in Tables 1 and 2 and plotted in Figures 1 and 2.

\section{HOLE 367}

The basalts penetrated by Hole 367 at a depth of 1144-1153 meters are basement basalts. Microscopic study showed that they are amygdaloidal and that the amygdules are filled with chlorite and the differently crystallized groundmass. Three types of basalts have been distinguished depending on the degree of crystallization:

1) Variolitic basalt with an intersertal texture of the groundmass (Sections 367-38-2, 367-39-2). It is composed of $40 \%$ plagioclase, $30 \%$ augite, $15 \%$ magnetite, $3 \%$ olivine, and $12 \%$ glass. Plagioclases are randomly oriented and form laths about $100 \mu \mathrm{m}$ in size. The extinction angle of the plagioclases suggests $\mathrm{An}_{30}-\mathrm{An}_{40}$ composition. They are usually clear, some show sericitization, and are replaced by epidote. The pyroxene, probably augite, is granular in shape. Magnetite has cruciform skeletal and prismatic habit. Olivine is slightly altered and chloritized. Glass is locally altered into a mixture of palagonite, chlorite, or caladonite and carbonate. The mineral paragenesis is plagioclase-pyroxene and olivine-magnetite glass.

2) Vitric basalt (Section 367-40-1), consists of $60 \%$ glass, $15 \%$ plagioclase, $15 \%$ augite, and $10 \%$ magnetite. Plagioclase and pyroxene form microphenocrysts which are intimately intergrown and form feathery aggregates. Glass is clear and magnetite forms cruciform skeletal crystals. Chalcedony fills some of the vesicles and fractures.

3) Trachytic basalt (Section 40-1) is composed of $40 \%$ plagioclase, $35 \%$ glass, $15 \%$ magnetite, and $5 \%$ augite. Groundmass has a trachytic texture. Plagioclase is altered into a mixture of sericite and epidote and glass is altered into palagonite. Magnetite has skeletal cruciform habit. Augite has not been observed, but some of the chlorite has crystallographic outlines suggesting that it is replacing augite.

The chemical composition of two basalt samples is presented in Table 1. The basalts belong to tholeiitic basalts with a low $\mathrm{K}_{2} \mathrm{O}$ content. Figure 1 shows that the two samples are located in the development field of abyssal tholeiites, rocks of the island arcs, and tholeiites of Iceland and the Hawaiian Islands. Section 367-39-2 falls into the development field of alkaline rocks of the Iceland and Atlantic islands. It can be seen on Figure 2 that the basalts are in the field of oceanic tholeiitic basalts.
TABLE 1

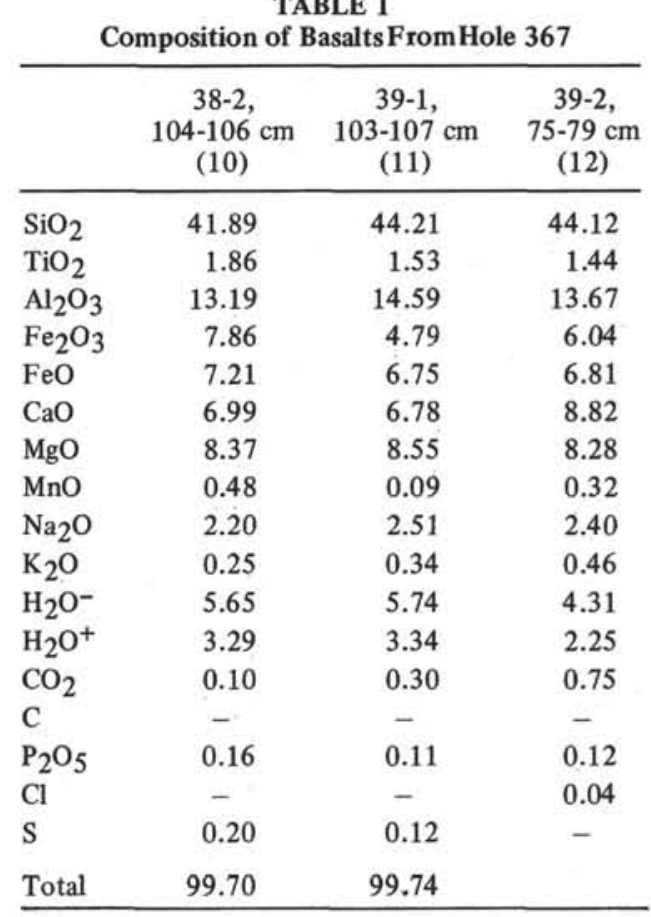

\section{HOLE 368}

Hole 368 penetrated through a diabasic sill which is the apophysis of a large intrusive body. Judged by microscopic data, the central part of the sill is composed of gabbro-diabases and olivinic diabases. Tholeiitic basalts and trachybasalts are developed in the marginal parts. Trachybasalts of the lowermost parts of the sill are similar to those from the upper part. In the zone of contact with clay shales, there are intrusions of trachybasalts into the clay mass. Gabbrodiabases and olivine diabases are final products of crystallization of primary basaltic magma.

Below is the description of the rock varieties concerned:

1) Gabbro-diabase (Samples 368-61-1, 143-145 cm, $368-61-3,52-54 \mathrm{~cm}, 368-63-3,4-6 \mathrm{~cm}$ ) consists of $40 \%$ plagioclase, $33 \%$ pyroxene, $6 \%$ hornblende, $2 \%$ ferruginous chlorite, $3 \%$ magnetite and ilmenite, $1 \%$ quartz, and $1 \%$ calcite. The structure of the rock is hypidiomorphic. A greater part of the plagioclase crystals is fresh and unaltered, with their composition varying within $\mathrm{An}_{35}$ and $\mathrm{An}_{60}$. A lesser part of the crystals of the earlier stage of formation relates to bytownite and that of the later stage, to andesite. Plagioclase was crystallized before pyroxene. The composition of the greater part of the pyroxene crystals 
TABLE 2

Composition of Gabbro-Diabase, Diabase, and BasaltsFrom Hole 368

\begin{tabular}{|c|c|c|c|c|c|c|c|}
\hline & $\begin{array}{c}60-5 \\
139-141 \mathrm{~cm} \\
(13)\end{array}$ & $\begin{array}{c}60-4, \\
74-80 \mathrm{~cm} \\
(14)\end{array}$ & $\begin{array}{c}61-2 \\
101-103 \mathrm{~cm} \\
(15)\end{array}$ & $\begin{array}{c}62-1 \\
117-119 \mathrm{~cm} \\
(16)\end{array}$ & $\begin{array}{c}61-2, \\
143-145 \mathrm{~cm} \\
(17)\end{array}$ & $\begin{array}{l}62-3 \\
11-13 \mathrm{~cm} \\
(18)\end{array}$ & $\begin{array}{c}63-3 \text {, } \\
4-6 \mathrm{~cm} \\
(19)\end{array}$ \\
\hline $\mathrm{SiO}_{2}$ & 51.15 & 47.81 & 47.63 & 46.20 & 47.43 & 55.81 & 38.36 \\
\hline $\mathrm{TiO}_{2}$ & 0.94 & 0.94 & 0.89 & 0.85 & 0.89 & 0.72 & 1.15 \\
\hline $\mathrm{Al}_{2} \mathrm{O}_{3}$ & 13.47 & 12.86 & 12.81 & 13.19 & 12.98 & 14.26 & 16.04 \\
\hline $\mathrm{Fe}_{2} \mathrm{O}_{3}$ & 4.92 & 4.42 & 4.96 & 4.99 & 4.75 & 1.91 & 4.66 \\
\hline $\mathrm{FeO}$ & 5.84 & 7.39 & 6.42 & 7.15 & 6.62 & 3.64 & 6.89 \\
\hline $\mathrm{CaO}$ & 7.40 & 9.98 & 11.08 & 9.83 & 10.84 & 8.00 & 14.40 \\
\hline $\mathrm{MgO}$ & 6.05 & 7.18 & 9.11 & 9.29 & 9.13 & 2.25 & 3.42 \\
\hline $\mathrm{MnO}$ & 0.12 & 0.16 & 0.17 & 0.16 & 0.16 & 0.25 & 0.21 \\
\hline $\mathrm{Na}_{2} \mathrm{O}$ & 2.47 & 2.51 & 2.32 & 2.32 & 2.32 & 1.59 & 2.76 \\
\hline $\mathrm{K}_{2} \mathrm{O}$ & 1.04 & 0.54 & 0.42 & 0.46 & 0.42 & 2.20 & 0.54 \\
\hline $\mathrm{H}_{2} \mathrm{O}^{-}$ & 2.83 & 2.11 & 2.63 & 2.76 & 2.96 & 0.88 & 2.15 \\
\hline $\mathrm{H}_{2} \mathrm{O}^{+}$ & 1.38 & 1.21 & 0.98 & 1.66 & 0.99 & 2.86 & 1.82 \\
\hline $\mathrm{CO}_{2}$ & 1.90 & - & - & - & - & 4.90 & 7.05 \\
\hline $\mathrm{C}^{2}$ & 0.15 & - & - & - & - & - & - \\
\hline $\mathrm{P}_{2} \mathrm{O}_{5}$ & 0.10 & 0.17 & 0.09 & 0.01 & 0.09 & 0.12 & 0.09 \\
\hline $\mathrm{S}$ & - & 0.04 & 0.04 & - & - & 0.16 & 0.04 \\
\hline $\mathrm{Cl}$ & - & 1.28 & - & - & - & 0.46 & 0.82 \\
\hline Total & 99.76 & 99.60 & 99.55 & 99.55 & 99.58 & 99.98 & 100.40 \\
\hline
\end{tabular}

corresponds to titanium-augite, and some part to hypersthene. Both varieties were crystallized simultaneously. The hypersthene crystals frequently include grains of olivine and plagioclase. Bluish-green amphibole, greenish-brown hornblende, and brown ferruginous chlorite are products of autometamorphism and were crystallized at a later stage. Ilmenite and magnetite occur as skeletal aggregates. Quartz is intergrown into augite. Calcite fills the spaces between laths of feldspars. Table 2 presents a complete composition of gabbro-diabases. Figure 1 shows that the composition of the gabbro-diabases is in the field of tholeiitic basalts of the Hawaiian Islands, Iceland, and rocks of the Iceland arcs. The results of the two analyses presented in Figure 2 lie in the field with a higher $\mathrm{FeO}$ content; Sample $368-61-2,143-145 \mathrm{~cm}$ is in the field of tholeiitic basalts.

2) Olivine diabase (Sample $368-60-5,139-141 \mathrm{~cm}$ ) is composed of $55 \%$ plagioclase, $5 \%$ pyroxene, $10 \%$ olivine, $20 \%$ hornblende, $7 \%$ chloritized glass, $1 \%$ ferric oxides, and $2 \%$ calcite. The composition of the larger part of the plagioclase crystals varies within Anso and Anoo. Pyroxene occurs as augite replaced by serpentinite. Olivine forms long crystals replaced entirely by talc and serpentine. Interstitial spaces are filled with hornblende, chlorite, calcite, and chalcedony. Ilmenite, magnetite, and hematite are intergrown into pyroxene.

From the chemical composition, the basalts are similar to alkaline rocks of Iceland, the islands of the
Atlantic Ocean, and east Asia. In Figure 2 the diabase occurs in the field of tholeiitic basalts. In the marginal parts of the intrusive body basalts occur, among which are trachybasalts (Sample 368-62-3, 11-13 cm, 368-61-2, 101-103 cm) and tholeiitic basalts (Samples 368-60-4, $74-80 \mathrm{~cm}, 368-60-5,121-123 \mathrm{~cm}$ ).

3) Trachybasalt is characterized by typical microtrachytic structure of the groundmass and impregnations of plagioclase represented by labradorite (Anso$\left.\mathrm{An}_{60}\right)$ and ilmenite.

4) Tholeiitic basalt is composed of plagioclase, basaltic hornblende considerably replaced by palagonite, and serpentinite. The plagioclase content is about $60 \%$, its composition corresponding to labradorite $\left(\mathrm{An}_{50}-\mathrm{An}_{60}\right)$. The basaltitic hornblende (about $30 \%$ ) is associated with sideromelane, chlorophaeite, serpentinite, and fills the spaces between laths of plagioclases. Hematite and ilmenite comprise $5 \%$, being arranged between the laths of plagioclase. Calcite, about $5 \%$, usually occurs on the hornblende. The basalts are similar to tholeiitic basalts of the Hawaiian islands and Icelandic alkaline rocks. The trachybasalt sample is similar to alkaline rocks of east Asia. In Figure 2 the sample appears in the field with higher contents of $\mathrm{FeO}, \mathrm{Na}_{2} \mathrm{O}$, and $\mathrm{K}_{2} \mathrm{O}$. The rest of the samples in Figure 2 appear in the field of tholeiitic basalts. 


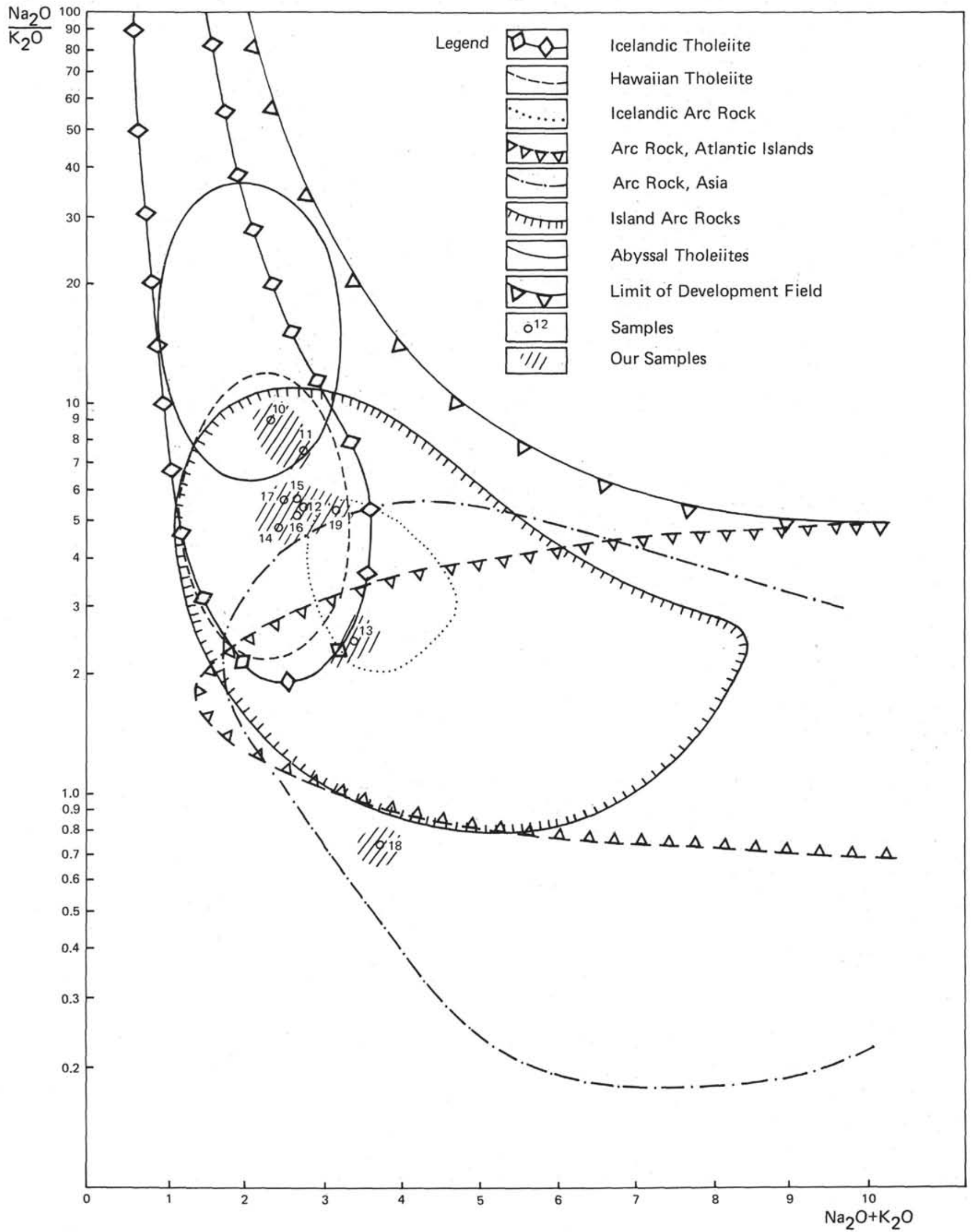

Figure 1. Basalts from Holes 367 and 368 compared to stability fields of other basalts. 
V. V. EREMEEV

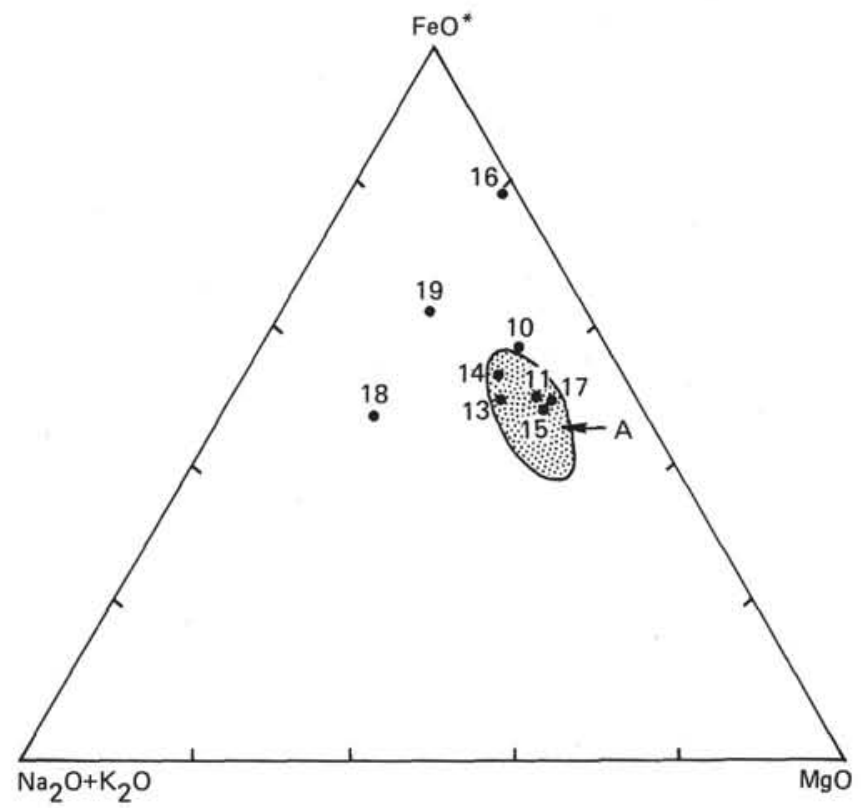

Figure 2. Basalts from Holes 367 and 368. 